Arq. Bras. Med. Vet. Zootec., v.63, n.1, p.67-73, 2011

\title{
Cryotop and development of vitrified immature bovine oocytes
}

[Cryotop no desenvolvimento de oócitos bovinos imaturos vitrificados]

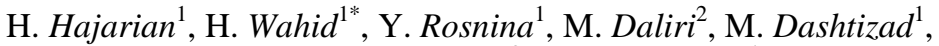 \\ H. Karamishabankareh ${ }^{3}$, O. Abas Mazni ${ }^{4}$ \\ ${ }^{1}$ Faculty of Veterinary Medicine - Universiti Putra Malaysia \\ 43400 - Serdang, Selangor, Malaysia \\ ${ }^{2}$ Department of Animal Biotechnology, National Institute of Genetic Engineering and \\ Biotechnology - Tehran, Iran \\ ${ }^{3}$ Department of Animal Science, Faculty of Agriculture - Razi University - Kermanshah, Iran \\ ${ }^{4}$ Agro-Biotechnology Institute - Serdang, Malaysia
}

\begin{abstract}
The effectiveness of different cryodevices (open-pulled straw (OPS), electron microscopy grid (EMG), and Cryotop was evaluated for vitrification of immature bovine oocytes. Polar body, metaphase II stage (MII), survivability, and subsequent developmental rates were determined. Only oocytes with four or five layers of cumulus cells were used. Oocytes were equilibrated in two vitrification solutions -1 : $10 \%$ DMSO $+10 \%$ ethylene glycol (EG) for 30-45sec and 2: 20\% DMSO + 20\% EG +0.5M sucrose for 25sec -, mounted on one of the cryodevices and directly plunged into liquid nitrogen for 10 days. Immature vitrified oocytes using Cryotop showed the highest rates of polar body extrusion (PB) and nuclear maturity (MII); 41 and 58\% respectively. Vitrified oocytes using OPS and EMG showed 26 and 32\%; and 35 and 46\% of PB and MII rates, respectively. The highest survivability resulted from Cryotop and EMG groups and no significant difference was found between them. Vitrified oocytes using Cryotop had the highest cleavage and blastocyst rates. All of the mean rates for vitrified immature oocytes were significantly lower than that of control group $(\mathrm{P}<0.05)$. The results of this study showed the superiority of Cryotop device for vitrification of immature bovine oocytes.
\end{abstract}

Keywords: bovine, immature oocyte, vitrification, cryodevice

\section{RESUMO}

Avaliou-se a eficácia de diferentes dispositivos de congelamento (envasamento em palhetas (EP), microscopia eletrônica de grade (MEG) e Cryotop) para vitrificação de ovócitos imaturos de bovinos. Para tal, foram determinados o corpo polar, a metáfase II (MII), a viabilidade e as subsequentes taxas de desenvolvimento. Foram utilizados somente ovócitos com quatro ou cinco camadas de células do cumulus. Os ovócitos foram equilibrados em duas soluções de vitrificação - 1: DMSO (10\%) + etilenoglicol (EG; 10\%) por 30 a 45 segundos e 2: DMSO (20\%) + EG (20\%) + sacarose (0,5M) por 25 segundos -, transferidos para os dispositivos de congelamento e mantidos, por 10 dias, em nitrogênio líquido. Imediatamente após serem retirados do nitrogênio, os ovócitos foram removidos dos dispositivos e processados para maturação, fertilização e cultivo in vitro. Os ovócitos vitrificados com o Cryotop apresentaram as maiores taxas de extrusão do corpo polar (CP) e de maturidade nuclear (MII), 41 e 58\%, respectivamente. Para os ovócitos vitrificados com EP e MEG, as taxas de CP e as de MII foram, respectivamente, de 26 e 32\% e de 35 e $46 \%$. As taxas de viabilidade não diferiram entre os grupos Cryotop e EMG. Os ovócitos vitrificados com Cryotop apresentaram as maiores taxas de clivagem e de blastocisto. Para todas as variáveis estudadas, as taxas para os ovócitos vitrificados foram significativamente menores do que as do grupo-controle $(P<0,05)$. Os resultados deste estudo mostraram a superioridade do dispositivo Cryotop para vitrificação de ovócitos imaturos de bovinos.

Palavras-chave: bovino, oócito imaturo, vitrificação, dispositivos de congelamento

Recebido em 19 de julho de 2010

Aceito em 10 de janeiro de 2011

*Autor para correspondência (corresponding author)

E-mail: wahid@vet.upm.edu.my 


\section{INTRODUCTION}

In 1985, vitrification emerged as another option for cryopreservation of cells and organs (Rall and Fahy, 1985). Formation of ice crystals is totally prevented in vitrification procedures using two main strategies: exceedingly high cooling/warming rates and highly viscose and concentrated vitrification solution (Smorag and Gajda, 1994; Vajta and Kuwayama, 2006). Some strategies such as reduction of vitrification solution volume (minimum volume, $\leq 1 \mu \mathrm{L}$ ) and direct contact with liquid nitrogen or slush liquid nitrogen help to obtain necessary high cooling/warming rates (Yavin and Arav, 2007). The minimum volume-direct contact approach has been employed for cryopreservation of extremely chill sensitive Drosophila eggs by loading them on electron microscopy grids (Mazur et al., 1992). Later on, Kuwayama et al. (2005a) invented the Cryotop method with the same technology like electron microscopy grid. The Cryotop technology allows loading of oocytes or embryos with minimum vitrification solution. Direct contact of minimized vitrification solution $(\sim 0.1 \mu \mathrm{L})$ to liquid nitrogen results in exceedingly high cooling rate $\left(>23,000^{\circ} \mathrm{C}\right)$. Thereafter, the danger zone temperatures $\left(15^{\circ} \mathrm{C}\right.$ to $\left.-5^{\circ} \mathrm{C}\right)$ which attribute in chilling injury are easily skipped. Furthermore, minimizing of vitrification solution around the sample and direct contact facilitate achieving of extremely high warming rates $\left(>42,000^{\circ} \mathrm{C}\right)$, which has been found that it is more important to be fast enough and prevent devitrification at the time of warming (Isachenko et al., 2005a; Isachenko et al., 2005b). Cryotop have shown its superiority to OPS for vitrification of immature pig (Liu et al., 2008), human (Kuwayama et al., 2005b), and matured bovine oocytes (Morato et al., 2008), but there is still a gap of information for vitrification of immature bovine oocytes using different cryodevices.

Other issues that may profoundly affect the vitrification results are the species and developmental stages of oocyte or embryos. The reason is that permeability and sensitivity of gametes and embryos are different with relation to the species and developmental stages (Hochi et al., 1998; Men et al., 2002; Magnusson et al., 2008). Previous studies have shown that MII bovine oocytes have greater permeability to cryoprotectants and water than GV oocytes (Agca et al., 1998).

The aim of the present study is to compare the efficiency of three cryodevices namely openpulled straw (OPS), electron microscopy grid (EMG), and Cryotop on the viability, cleavage, and blastocyst rates of immature bovine oocytes.

\section{MATERIAL AND METHODS}

Unless otherwise indicated, all chemicals were purchased from Sigma-Aldrich (St. Louis, MO, USA).

Ovaries were collected from local abattoirs and transported to the laboratory within three hours at $34-36^{\circ} \mathrm{C}$ in phosphate-buffer saline (PBS; P4417) containing penicillin-streptomycin $(100,000 \mathrm{IU}$ of penicillin and $100 \mathrm{mg}$ of streptomycin per liter). Cumulus-oocyte complexes (COC) were obtained by slicing method in tissue culture medium 199 (Medium199, 12340; Gibco) containing 25mM HEPES, Earl's salts, L-glutamine, and $2 \mathrm{mg} / \mathrm{mL}$ sodium bicarbonate modified by the addition of $4 \mathrm{mg} / \mathrm{mL}$ bovine serum albumin (BSA, fraction $\mathrm{V}, \mathrm{A}-3311)$ and gentamycin $50 \mu \mathrm{g} / \mathrm{mL}$ (G-1264).

Recovered oocytes were washed twice in holding solution (HS, Hepes-buffered TCM medium supplemented with $20 \%$ fetal calf serum, FCS) and kept there for about 15min. Groups of four COC were incubated in the first vitrification solution (VS1: 10\% DMSO and 10\% EG in WS) for 35-40sec and then transferred to the second vitrification solution (VS2: 20\% DMSO, 20\% $\mathrm{EG}$, and $0.5 \mathrm{M}$ sucrose in WS) for $25 \mathrm{sec}$. Instantly, oocytes were loaded on cryodevices including OPS, EMG, and Cryotop (Kitazato Supply Co, Fujinomiya, Japan) and submerged into liquid nitrogen $\left(\mathrm{LN}_{2}\right)$ for storage. The time of exposure from VS2 to $\mathrm{LN}_{2}$ was not longer than 30s. Vitrified samples were maintained in $\mathrm{LN}_{2}$ for at least 10 days.

Immediately after removing of cryodevices from $\mathrm{LN}_{2}$, they were submerged in 3-mL pre-warmed $\left(39^{\circ} \mathrm{C}\right)$ HS plus $0.25 \mathrm{M}$ sucrose (T1) and smoothly tried to remove oocytes from cryodevices. Immature oocytes were left in T1 for $5 \mathrm{~min}$ and then transferred to HS plus $0.15 \mathrm{M}$ sucrose solution for $5 \mathrm{~min}$. Finally, the immature oocytes were washed twice in HM for 5 min each 
and processed for in vitro maturation, fertilization, and culture.

Immature oocytes were washed two times in medium 199 supplemented with 4mg/mL BSA and washed again in maturation solution containing Hepes-buffered medium 199 supplemented with $10 \%$ fetal calf serum, $0.2 \mathrm{mM}$ sodium pyruvate (P-5280), $50 \mu \mathrm{L} / \mathrm{mL}$ Gentamycin (G-1264), and $1 \mu \mathrm{g} / \mathrm{mL}$ oestradiol$17 \beta$ (E-8875). Approximately 20-30 oocytes were incubated in $400 \mu \mathrm{L}$ of maturation solution under mineral oil in 4-well plates for 22-24h at $38.5^{\circ} \mathrm{C}$ under $5 \% \quad \mathrm{CO}_{2}$ atmosphere with high humidity. The vitrified BCB-test separated oocytes also underwent the same maturation process with control group after warming.

For the purpose of maturation determination, 24 hours after maturation, oocytes were denuded using $0.1 \%(\mathrm{w} / \mathrm{v})$ hyaluronidase (Type $1-\mathrm{S})$ in Hepes-buffered medium 199 by vortexing. The cumulus-free oocytes were fixed in aceto-ethanol mixture $(1: 3, v / v)$ at $5^{\circ} \mathrm{C}$ for 24 hours. Once fixed, oocytes in groups from five to 10 were mounted on slides. Cover-slip with four spots of silicon glued at the corners was gently pressed down until it touched and secured the oocytes. Afterward, aceto-lacmoid stain was passed under the cover-slip and remained there for $5 \mathrm{~min}$ followed by staining. A decolorizing solution (aceto-glycerol) was passed through to remove the stain residuals. Stained oocytes were examined under stereomicroscope (40x) for determination of nuclear stages.

The fertilization method was previously described by Parrish et al. (1988) with some modifications. Briefly, matured oocytes were washed three times in tyrode's albumin lactate pyruvate buffered with HEPES (Talp-Hepes) and twice in fertilization medium. Viable spermatozoa were obtained by centrifugation of frozen-thawed spermatozoa on Bovipure (Nidacon International AB, Gothenburg, Sweden) discontinuous density gradient $(2 \mathrm{~mL}$ of top-layer over $2 \mathrm{~mL}$ of bottom-layer) for $20 \mathrm{~min}$ at $300 \mathrm{x} g$ at room temperature. Viable spermatozoa, collected at the bottom of the tube, were washed with $5 \mathrm{~mL}$ of sperm-TALP supplemented by $6 \mathrm{mg} / \mathrm{mL}$ BSA (fraction V, A3311) and centrifuged for $10 \mathrm{~min}$ at $300 \mathrm{x} \mathrm{g}$. After centrifugation, $150 \mu \mathrm{L}$ of the pellet were selected. Spermatozoa were counted in a hemacytometer and diluted in the appropriate volume of IVF-Talp to give a concentration of $1 \times 10^{6}$ spermatozoa/mL. IVM-oocytes were transferred in groups of up to seven into $50 \mu \mathrm{L}$ of fertilization solution supplemented with 10 $\mu \mathrm{g} / \mathrm{mL}$ heparin-sodium salt (Sigma, H-3393). Spermatozoa suspension was added to each fertilization droplet. Oocytes and sperms were incubated for $18 \mathrm{~h}$ at $38.5^{\circ} \mathrm{C}$ in $5 \% \mathrm{CO}_{2}$ in humidified air.

Eighteen hours after IVF, oocytes were freed of cumulus cells by high speed vortexing and washed twice in Talp-Hepes and culture medium. For each well, 10-15 oocytes were transferred to $400 \mu \mathrm{L}$ of synthetic oviductal fluid (SOFaaci) supplemented with $5 \%$ adult bovine serum (B-9433) and $1 \mu \mathrm{g} / \mathrm{mL}$ gentamycin under mineral oil. Every two days after transfer to culture medium, $200 \mu \mathrm{L}$ of culture medium were replenished with $200 \mu \mathrm{L}$ fresh incubated SOF medium. Cleavage and blastocyst rates were recorded at $48 \mathrm{~h}$, seven and nine days post insemination, respectively.

Two experiments were performed to find out the in vitro viability of immature oocytes after vitrification using EMG, cryotop, and OPS. In the first experiment, some of the vitrified/warmed immature oocytes were matured and freed of cumulus cells at 22-24h of maturation. Oocytes were monitored for the presence of polar body. Afterward, the oocytes were fixed and stained. Nuclear maturation stages for each group were determined under the light microscope. In the second experiment, survivability, cleavage ( $\geq 8$-cell), and blastocyst rates were evaluated at $24 \mathrm{~h}$ after IVM, 40-48h post insemination (hpi), 4-5 days post insemination (dpi), and 7-10 dpi, respectively.

All experiments were repeated six times. Significant differences among treatments were revealed by non parametric one-way analysis of variance followed by Duncan's multiple range test for mean comparisons $(\mathrm{P}<0.05)$ using SAS software ver. 9.1 (SAS Inst., Cary, NC).

\section{RESULTS}

Polar body assessment of denuded oocytes revealed that vitrification using Cryotop increased the percentage of oocytes with extruded polar body $(\mathrm{P}<0.05$; Table 1$)$. Polar 
body rate was significantly lower in Cryotop when compared with control group $(\mathrm{P}<0.05)$. Although degeneration happened in higher rate in OPS group $(\mathrm{P}<0.05)$, control group showed the least degeneration followed by Cryotop.
There was no significant difference regarding the absence of polar body (PB-) between OPS, Cryotop, and EMG groups $(\mathrm{P}>0.05)$, but control group represented the lowest percentage of $\mathrm{PB}$ compared with other groups $(\mathrm{P}<0.05$; Table 1$)$.

Table 1. Polar body rate after in vitro maturation in different cryodevices

\begin{tabular}{lcccc}
\hline Oocytes & $\begin{array}{c}\text { OPS } \\
(\mathrm{n}=49)\end{array}$ & $\begin{array}{c}\text { Cryotop } \\
(\mathrm{n}=58)\end{array}$ & $\begin{array}{c}\text { EMG } \\
(\mathrm{n}=77)\end{array}$ & $\begin{array}{c}\text { Control } \\
(\mathrm{n}=69)\end{array}$ \\
\hline Polar body + & $10(26 \%) \mathrm{c}$ & $24(41 \%) \mathrm{b}$ & $24(32 \%) \mathrm{c}$ & $48(70 \%) \mathrm{a}$ \\
Polar body - & $27(50 \%) \mathrm{a}$ & $26(45 \%) \mathrm{a}$ & $39(52 \%) \mathrm{a}$ & $20(29 \%) \mathrm{b}$ \\
Degenerated & $12(24 \%) \mathrm{a}$ & $8(14 \%) \mathrm{b}$ & $14(18 \%) \mathrm{ab}$ & $1(1 \%) \mathrm{c}$
\end{tabular}

OPS: open-pulled straw; EMG: electron microscopy grid.

Data were pooled from four replicates.

Values in the same row with followed by distinct letters differ $(\mathrm{P}<0.05)$.

Vitrified/warmed immature oocytes in Cryotop group were seen in MII stage of maturation (58\%), significantly higher compared with EMG and OPS groups (46\% and 35\%, respectively). Oocytes in Cryotop and EMG groups tended to pursue their maturation and had less germinal vesicle $(\mathrm{GV})$ stage oocytes in comparison to OPS group $(\mathrm{P}<0.05$; Table 2$)$. There was no significant difference in percentage of GVBDMI among all groups. In comparison with the other groups, the least $\mathrm{GV}$ and GVBD-MI rate resulted from control group $(\mathrm{P}<0.05)$.

Table 2. Nuclear maturation of vitrified immature oocytes

\begin{tabular}{cccccc}
\hline Nuclear stage & $\begin{array}{c}\text { OPS } \\
(\mathrm{n}=37)\end{array}$ & $\begin{array}{c}\text { Cryotop } \\
(\mathrm{n}=50)\end{array}$ & $\begin{array}{c}\text { EMG } \\
(\mathrm{n}=63)\end{array}$ & $\begin{array}{c}\text { Control } \\
(\mathrm{n}=68)\end{array}$ \\
\hline GV & $15(41 \%) \mathrm{a}$ & $8(16 \%) \mathrm{c}$ & $16(25 \%) \mathrm{b}$ & $4(6 \%) \mathrm{d}$ \\
GVBD-MI & $6(16 \%) \mathrm{a}$ & $10(20 \%) \mathrm{a}$ & $13(20 \%) \mathrm{a}$ & $2(2.5 \%) \mathrm{b}$ \\
MII & $13(35 \%) \mathrm{d}$ & $29(58 \%) \mathrm{b}$ & $29(46 \%) \mathrm{c}$ & $60(88 \%) \mathrm{a}$ \\
Unclassified & $3(7 \%)$ & $3(5 \%)$ & $5(7 \%)$ & $2(2 \%)$ \\
\hline
\end{tabular}

OPS: open pulled straw; EMG: electron microscopy grid; GV: germinal vesicle;

GVBD-MI: GV breakdown, metaphase of the first meiotic division; MII: metaphase of the second meiotic division.

Data were pooled from four replicates.

Values in the same row followed by distinct letters differ $(\mathrm{P}<0.05)$.

Table 3 provides the results obtained from viability, cleavage ( $\geq 8$ cells), and blastocyst rates of vitrified/warmed immature bovine oocytes. It is apparent from this table that oocytes from Cryotop and EMG group (90\% and 89\%, respectively) had significantly higher viability compared with OPS group (79\%; $\mathrm{P}<0.05)$. However, viability rate of control group (100\%) was significantly higher than treated groups. Some of the treated oocytes lost their survivability during IVF. Presence of multiple spermatozoa in the perivitelline space of vitrified/warmed oocytes was also noticeable. The rate of cleaved oocytes was significantly higher in the Cryotop group $(40.21 \pm 4.21 \%)$ compared to EMG and OPS (33.29 \pm 1.35 and
30.94 \pm 1.61 , respectively), but there was no difference between EMG and OPS groups. Developmental rate of embryos to 8-cell or beyond was significantly higher $(\mathrm{P}<0.05)$ in Cryotop group (23.33 $\pm 1.62 \%)$ than other groups (17.15 $\pm 3.22 \%, 12.91 \pm 2.00 \%$ for OPS and EMG, respectively). Although, no significant difference in blastocyst formation was revealed among treated groups $(\mathrm{P}<0.05)$, Cryotop resulted in higher percentage of blastocyst rate compared with other groups ( $>0.05$; Table 3$)$. All of the mean rates for vitrified/warmed immature oocytes were significantly lower than that of control group $(\mathrm{P}<0.05)$. 
Table 3. In vitro viability of vitrified-warmed immature bovine oocytes equilibrated at different temperatures

\begin{tabular}{lccccc}
\hline Treatment & $\begin{array}{c}\text { No. of } \\
\text { oocytes }\end{array}$ & $\begin{array}{c}\text { Viability } \\
(\%)\end{array}$ & $\begin{array}{c}\text { Cleaved } \\
\text { oocytes }(\%)\end{array}$ & $\begin{array}{c}\geq 8 \text { cell-embryos } \\
(\%)\end{array}$ & $\begin{array}{c}\text { Blastocyst } \\
(\%)\end{array}$ \\
\hline Control & 174 & $100 \mathrm{a}$ & $75.70 \pm 3.93 \mathrm{a}$ & $61.46 \pm 3.10 \mathrm{a}$ & $35.62 \pm 2.06 \mathrm{a}$ \\
OPS & 133 & $79.63 \pm 2.06 \mathrm{c}$ & $30.94 \pm 1.61 \mathrm{c}$ & $12.91 \pm 2.00 \mathrm{~d}$ & $2.85 \pm 2.27 \mathrm{~b}$ \\
Cryotop & 104 & $90.34 \pm 2.49 \mathrm{~b}$ & $40.21 \pm 4.21 \mathrm{~b}$ & $23.33 \pm 1.62 \mathrm{~b}$ & $4.88 \pm 2.72 \mathrm{~b}$ \\
EMG & 153 & $89.20 \pm 2.36 \mathrm{~b}$ & $33.29 \pm 1.35 \mathrm{c}$ & $17.15 \pm 3.22 \mathrm{c}$ & $3.61 \pm 2.16 \mathrm{~b}$ \\
\hline
\end{tabular}

OPS: open-pulled straw; EMG: electron microscopy grid.

Data were pooled from six replicates.

Values in the same column followed by distinct letters differ $(\mathrm{P}<0.05)$.

\section{DISCUSSION}

In this study, three efficient cryodevices used for vitrification of immature bovine oocytes were compared. The reason was to standardize usage of a cryodevice, which results in a higher cooling/warming rate, better protection, and higher viability after warming. Cryotop resulted in higher viability compared to other treated groups.

Survivability of immature bovine oocytes was assessed by recovery of oocytes after warming, existence of polar body, and by staining for nuclear maturation. Nuclear maturation rate of vitrified immature oocytes by Cryotop device was comparably higher than other cryodevices demonstrating the ability of immature oocytes to survive vitrification. Nuclear maturity of vitrified immature bovine oocytes were comparably lower in previous published studies (Cetin and Bastan, 2006; Yamada et al., 2007) than in this experiment.

Two major obstacles which are overcome by vitrification procedure are ice crystal formation and chilling injury (Vajta and Kuwayama, 2006). Chilling injury mostly affects cytoskeleton and cell membranes including oolema and membrane of organelles (Morato et al., 2008). For vitrification process and prevention of intracellular ice formation, two main approaches are necessary, which are high concentrations of permeating cryoprotectants (CPA, around 6-8M) and high cooling/warming rates. The higher viability resulted from Cryotop and EMG represents improvements over the rates obtained by OPS device and can be attributed to the higher cooling/warming rates obtained using the Cryotop and EMG technologies. EMG has been employed for cryopreservation of extremely chill sensitive Drosophila eggs by loading them on
EMG (Mazur et al., 1992). It has been said that the basis of Cryotop device was obtained from EMG device. On the other hand, the Cryotop technology (Kuwayama et al., 2005a) allows loading of oocytes or embryos with minimum vitrification solution. Even after mounting of sample on Cryotop, the excessive amount of vitrification solution is aspirated. Direct contact of minimized vitrification solution $(\sim 0.1 \mu \mathrm{L})$ to liquid nitrogen results in exceedingly high cooling rate $\left(>23,000^{\circ} \mathrm{C}\right)$. Thereafter, the danger zone temperatures $\left(15\right.$ to $\left.-5^{\circ} \mathrm{C}\right)$ which attributed in chilling injury are easily skipped. Furthermore, minimizing of vitrification solution around the sample facilitates achieving of extremely high warming rates $\left(>42,000^{\circ} \mathrm{C}\right)$, which has been found that it is more important to be fast enough and prevent devitrification at the time of warming (Isachenko et al., 2005a; Isachenko et al., 2005b).

The percentage of cleaved oocytes and $\geq 8$ cell embryos were higher in Cryotop followed by EMG. Hence, it seems that Cryotop could better preserve the cell structure and consequently fertilization capacity of vitrified immature oocytes. However, these results were significantly lower than those of fresh immature oocytes (control group). This reduction in cleavage rate of EMG group oocytes and subsequent development of them might be a result of mishandling of the device in which the EMG is tiny and has to be delicately handled. At the time of warming, some of them were positioned face down and subsequently damaged the oocytes. During that time, EMG should be handled using a fine forceps, pre-equilibrated in liquid nitrogen. In some cases, because of boiling of liquid nitrogen and searching for tiny grid and also transmission of body temperature to the forceps, its temperature goes up, and at the time of grabbing the grid, which creates a temperature 
shock and may cause devitrification. These results therefore need to be interpreted with caution.

Although the percentage of blastocyst formation was not significantly different, Cryotop resulted in higher blastocyst rate and showed its superiority over the other two cryodevices. However, comparison of blastocyst formation among treated groups and fresh group indicated that damage resulted from vitrification could compromise the viability and subsequent development of the vitrified immature oocytes. These results are consistent with the results from Morato et al. (2008) and Chian et al. (2004) which reported the superiority of Cryotop versus OPS.

In conclusion, the minimum volume-direct contact approach employed for Cryotop technology may provide enough support for vitrification of immature bovine oocytes. Further studies to employ Cryotop technology using its improved vitrification solution needs to be performed, which may provide better environment for vitrification of immature bovine oocytes and its subsequent development.

\section{ACKNOWLEDGEMENTS}

This research was supported by a grant from the National Institute of Genetic Engineering and Biotechnology (NIGEB), Ministry of Science, Technology, and Innovation, Iran (vote no. 382), - Dr. Morteza Daliri.

\section{REFERENCES}

AGCA, Y.; MONSON, R.L.; NORTHEY, D.L. et al. Normal calves from transfer of biopsied sexed and vitrified IVP bovine embryos. Theriogenology, v.50, p.129-145, 1998.

CETIN, Y.; BASTAN, A. Cryopreservation of immature bovine oocytes by vitrification in straws. Anim. Reprod. Sci., v.92, p.29-36, 2006.

CHIAN, R.-C.; KUWAYAMA, M.; TAN, L. et al. High survival rate of bovine oocytes matured in vitro following vitrification. J. Reprod. Dev., v.50, p.685-696, 2004.
HOCHI, S.; ITO, K.; HIRABAYASHI, M. et al. Effect of nuclear stages during IVM on the survival of vitrified-warmed bovine oocytes. Theriogenology, v.49, p.787-796, 1998.

ISACHENKO, $\quad$ V.; MONTAG, M.; ISACHENKO, E. et al. Vitrification of mouse pronuclear embryos after polar body biopsy without direct contact with liquid nitrogen. Fert. Steril., v.84, p.1011-1016, 2005a.

ISACHENKO, V.; MONTAG, M.; ISACHENKO, E. et al. Aseptic technology of vitrification of human pronuclear oocytes using open-pulled straws. Hum. Reprod., v.20, p.492496, 2005b.

KUWAYAMA, M.; VAJTA, G.; KATO, O. et al. Highly efficient vitrification method for cryopreservation of human oocytes. Reprod. Biomed. Online, v.11, p.300-308, 2005a.

KUWAYAMA, M.; VAJTA, G.; KATO, O. et al. Highly efficient vitrification method for cryopreservation of human oocytes. Reprod. Biomed. Online, v.11, p.300-308, 2005b.

LIU, Y.; DU, Y.; LIN, L. et al. Comparison of efficiency of open pulled straw (OPS) and Cryotop vitrification for cryopreservation of in vitro matured pig oocytes. CryoLetters, v.29, p.315-320, 2008.

MAGNUSSON, V.; FEITOSA, W.B.; GOISSIS, M.D. et al. Bovine oocyte vitrification: Effect of ethylene glycol concentrations and meiotic stages. Anim. Reprod. Sci., v.106, p.265-273, 2008.

MAZUR, P.; COLE, K.; HALL, J. et al. Cryobiological preservation of Drosophila embryos. Science, v.258, p.1932-1935, 1992.

MEN, H.; MONSON, R.L.; RUTLEDGE, J.J. Effect of meiotic stages and maturation protocols on bovine oocyte's resistance to cryopreservation. Theriogenology, v.57, p.10951103, 2002.

MORATO, R.; IZQUIERDO, D.; PARAMIO, M.T. et al. Cryotops versus open-pulled straws (OPS) as carriers for the cryopreservation of bovine oocytes: effects on spindle and chromosome configuration and embryo development. Cryobiology, v.57, p.137-141, 2008. 
PARRISH, J.J.; SUSKO-PARRISH, J.; WINER, M.A. et al. Capacitation of bovine sperm by heparin. Biol. Reprod., v.38, p.1171-1180, 1988.

RALL, W.F.; FAHY, G.M. Ice-free cryopreservation of mouse embryos at -196 [deg]C by vitrification. Nature, v.313, p.573575, 1985.

SMORAG, Z.; GAJDA, B. Cryopreservation of mammalian ova and embryos by vitrification. Biotech. Adv., v.12, p.449-465, 1994.

VAJTA, G.; KUWAYAMA, M. Improving cryopreservation systems. Theriogenology, v.65, p.236-244, 2006.
YAMADA, C.; CAETANO, H.V.A.; SIMÕES, $\mathrm{R}$. et al. Immature bovine oocyte cryopreservation: Comparison of different associations with ethylene glycol, glycerol and dimethylsulfoxide. Anim. Reprod. Sci., v.99, p.384-388, 2007.

YAVIN, S.; ARAV, A. Measurement of essential physical properties of vitrification solutions. Theriogenology, v.67, p.81-89, 2007. 